\title{
BCAR1 wt Allele
}

National Cancer Institute

\section{Source}

National Cancer Institute. BCAR1 wt Allele. NCI Thesaurus. Code C52369.

Human BCAR1 wild-type allele is located within 16q22-q23 and is approximately $23 \mathrm{~kb}$ in length. This allele, which encodes breast cancer anti-estrogen resistance protein 1 , is involved in the mediation of signaling responses to cellular adhesion, cellular migration, growth factor stimulation, cytokine receptor eng agement, and bacterial infection. 